\title{
The Effects Of The Great Recession On Corporate Working Capital Management Practices
}

Rakesh Duggal, Southeastern Louisiana University, USA

Michael C. Budden, Southeastern Louisiana University, USA

\begin{abstract}
Working capital theory prescribes using the optimal amount of net working capital to maximize shareholder wealth. Evidence from multiple countries indicates a negative relationship between the cash conversion cycle or net working capital and firm profitability. However, severe economic conditions may force firms to change their inventory, accounts receivable, and/or accounts payable policies, causing the firms to use morelless net working capital. Taking a sample of non-financial S\&P 500 firms, many of which are multinationals, this study finds significant changes in the cash conversion cycle in 2010 for some industries. Also, it appears firms in general held more net working capital in order to face new economic challenges.
\end{abstract}

Keywords: Great Recession on Corporate Working Capital Management Practices

\section{INTRODUCTION}

orking capital management involves managing the firm's current assets and current liabilities and
optimally financing its net working capital needs, the difference between current assets and current
liabilities. Since net working capital is financed with long-term borrowing and/or equity and since these are more expensive sources of funding than vendor financing or short-term borrowing, it is generally considered efficient to strive for zero/minimal net working capital to manage the firm's operating cycle.

Theory of working capital management, ceteris paribus, emphasizes minimizing the firm's cash conversion cycle (CCC), which is defined as the time interval between cash disbursements and cash collections. Cash conversion cycle is estimated as follows:

Cash conversion cycle=Inventory/(One day's cost of goods sold)+Accounts receivable/(One day's sale)-Accounts payable/(One day's cost of goods sold)

The first term on the right hand side is called Days Inventory Held (DIH). The second term is called Average Collection Period or Days Sale Outstanding (DSO), which is a measure of how quickly a firm collects from its customers. All else being equal, the higher the values for DIH and DSO, the higher the firm's investment in its net working capital. The last term is called Days Payable Outstanding (DPO), a measure of vendor financing. A higher value for this term denotes a greater amount of vendor financing, all else being equal. A firm that minimizes its cash conversion cycle also minimizes its needs for net working capital, which, as already stated, is costly and affects the firm's cost of capital.

The recent recession, which began in December 2007 and officially ended in June 2009, took a heavy toll on U.S. businesses. During that period, U.S. corporations, operating on what they believed was an efficient frontier of working capital management, suddenly found they were struggling to survive as collections slowed and credit availability dried up. Admittedly, the great recession was a black swan kind of event, however it likely forced corporations to rethink their working capital management practices. This study investigates whether U.S. 
businesses, revised their policies in the aftermath of the recession causing cash conversion cycles to change. This could happen if firms changed their inventory, accounts receivable, and/or accounts payable policies. However, it is difficult to predict whether the average CCC increased or decreased post 2008. It is possible that firms tried to have more/less inventory on hand based on their recent experience or they tried to find more reliable vendors even if they were costlier, thus changing their DIH, DPO, and/or Cash Conversion Cycle. Similarly, firms likely changed their credit policies in light of their recent collection experiences that increased or decreased DSO. Nevertheless, even if there is no change in the CCC, given their traumatic experiences in 2008, U.S. firms may be expected to deal with the "new normal" efficient frontier by holding more cash to avoid the kind of credit crunch they faced during the recession.

\section{LITERATURE REVIEW}

Both academic studies and management surveys indicate the importance of managing the firm's cash conversion cycle. Shin and Soenen (1998), using a total of 58,985 U.S. observations in the 1975-1994 period, found a strong negative relationship between the cash conversion cycle and firm profitability. More recently, employing a sample of 88 firms listed on the NYSE, Gill et al. (2010) found a similar statistically significant relationship. Interestingly, studies from other countries report similar findings (See Deloof for Belgium, Ghosh and Maji, for India, Garcia et al. for Spain, Lazaridis and Tryfonidis for Greece). Surveys by Myers (2000) indicate that U.S. managers are aware of the benefits of lower investments in the firm's working capital and have been trying to lower these investments. U.S. firms reduced their DSO by 1.1 days and DIH by 4.5 days, and increased their DPO by 0.7 days over the five-year period prior to 2000. Overall, the average CCC declined by 6.3 days in the same period. More recent surveys indicate the cash conversion cycle may have reached a plateau (Myers, 2007).

\section{DATA, SAMPLE AND METHODOLOGY}

S\&P 500 firms were employed to test the study's hypotheses. Financial firms were excluded from the sample because the concepts of cash conversion cycle and net working capital are not applicable to the financial industry. Using Bloomberg as the data source, the study employed the following variables (Bloomberg mnemonics in parentheses):

Cash Conversion Cycle (CASH_CONVERSION_CYCLE)

Days Inventory Held (INVENT_DAYS)

Days Sale Outstanding (ACCT_RCV_TURN)

Days Payable Outstanding (ACCOUNTS_PAYABLE_TURNOVER)

Current Assets (BS_CUR_ASSET_REPORT)

Current Liabilities (BS_CUR_LIAB)

Net Working Capital/Sale $=($ Current Assets - Current Liabilities $) /$ Sales

Cash and Short-Term Investments (BS_CASH_NEAR_CASH_ITEM)

The 2007 values for the above variables were used as the benchmarks to which the post-recession 2010

values were compared. The 2011 data was incomplete for the sample and therefore was not used. Paired t tests were conducted to draw statistical inferences.

\section{FINDINGS}

Table 1 contains the mean values for the variables employed for 2007 and 2010 as well as the t-statistics for the differences in the mean values. The sample size is 422 firms. No significant change is seen between the pre and post-recession values in the average cash conversion cycle or its three components for the entire sample. 
Table 1

Means, standard deviations, and t-statistics for the working capital variables employed in the study.

\begin{tabular}{|c|c|c|c|}
\hline Variable & $\begin{array}{c}2007 \text { Mean } \\
\text { (Standard deviation) } \\
\mathrm{N}=422\end{array}$ & $\begin{array}{c}2010 \text { Mean } \\
\text { (Standard deviation) } \\
\mathrm{N}=\mathbf{4 2 2}\end{array}$ & t-Statistic \\
\hline Cash conversion cycle (CCC) & $\begin{array}{c}60.40 \text { days } \\
(77.71)\end{array}$ & $\begin{array}{c}61.94 \text { days } \\
(80.73)\end{array}$ & 0.28 \\
\hline Days inventory held (DIH) & $\begin{array}{c}70.73 \text { days } \\
(70.73)\end{array}$ & $\begin{array}{c}73.77 \text { days } \\
(75.27)\end{array}$ & 0.60 \\
\hline Days sale outstanding (DSO) & $\begin{array}{c}15.85 \text { days } \\
(27.13)\end{array}$ & $\begin{array}{c}17.24 \text { days } \\
(40.16)\end{array}$ & 0.59 \\
\hline Days payable outstanding (DPO) & $\begin{array}{c}9.85 \text { days } \\
(6.99)\end{array}$ & $\begin{array}{c}10.20 \text { days } \\
(8.07)\end{array}$ & 0.66 \\
\hline Current assets (CA) & $\begin{array}{c}\$ 6,054.89 \text { million } \\
(10,132,26)\end{array}$ & $\begin{array}{c}\$ 7,275.83 \text { million } \\
(12,474.30)\end{array}$ & 1.56 \\
\hline Current liabilities (CL) & $\begin{array}{c}\$ 5,201.49 \text { million } \\
(14,818.65)\end{array}$ & $\begin{array}{c}\$ 5,150.80 \text { million } \\
(11,128.65)\end{array}$ & -0.06 \\
\hline Net working capital/Sales (NWC/S) & $\begin{array}{c}0.17 \\
(0.31) \\
\end{array}$ & $\begin{array}{c}0.21 \\
(0.28) \\
\end{array}$ & $2.29 * *$ \\
\hline Cash and short-term investments (CSTI) & $\begin{array}{c}\$ 1,280 \text { million } \\
(2,990.09)\end{array}$ & $\begin{array}{c}\$ 1,853.82 \text { million } \\
(4,548.87)\end{array}$ & $2.62 * *$ \\
\hline
\end{tabular}

**Significant at $5 \%$ confidence or higher

The CCC value in 2010 is about 62 days, slightly higher than the pre-recession value, indicating that on average U.S. firms have to self-finance their operating cycle by another 1.5 days as compared to 2007. DIH, DSO, and DPO increased from 2007 to 2010. This implies firms have more funds tied up in inventories and accounts receivables and are using more vendor financing. However, none of the above changes are statistically significant. Further, firms have approximately $\$ 600$ million more in cash and short-term investments in the post-recession period, a statistically significant change. Finally, firms have approximately 4 cents more in net working capital for each dollar in sales in 2010 than 2007. This change is statistically significant at the $1 \%$ confidence level and includes changes in cash, inventories, and accounts receivable.

Significant industry differences with regard to working capital management policies have been recognized (Shin and Soenen, 1998). Therefore, the sample firms were segregated based on the industry type. The mean differences in the variable values for the pre and post-recession periods were calculated for each subsample. These findings are reported in table 2 .

Table 2

t-Statistics for the mean differences for the working capital variables for 2007 and 2010

\begin{tabular}{|c|c|c|c|c|c|c|c|c|c|}
\hline Variable & $\begin{array}{c}\text { Energy } \\
(n=43)\end{array}$ & $\begin{array}{c}\text { Materials } \\
(\mathbf{n}=\mathbf{3 0})\end{array}$ & $\begin{array}{c}\text { Industrials } \\
\quad(n=61)\end{array}$ & $\begin{array}{c}\text { Cons. } \\
\text { Discretionary } \\
(\mathbf{n}=\mathbf{8 0})\end{array}$ & $\begin{array}{l}\text { Cons. } \\
\text { Staples } \\
(n=42)\end{array}$ & $\begin{array}{c}\text { Health- } \\
\text { care } \\
(n=52)\end{array}$ & $\underset{(n=71)}{\text { IT }}$ & $\begin{array}{c}\text { Tele- } \\
\text { Comm. } \\
(\mathbf{n}=7)\end{array}$ & $\begin{array}{c}\text { Utilities } \\
(n=32)\end{array}$ \\
\hline $\mathrm{CCC}$ & -0.75 & 0.51 & $2.20 * *$ & -0.22 & $-2.10 * *$ & 0.09 & -1.35 & $1.96^{*}$ & $2.22 * *$ \\
\hline DIH & 1.83 & 1.33 & $2.57 * *$ & 0.12 & $-1.68 *$ & 0.40 & $9.14 * *$ & $-2.39 * *$ & $2.54 * *$ \\
\hline DSO & 1.44 & -1.24 & 1.11 & -0.41 & 1.19 & $-2.53 * *$ & $-5.58 * *$ & -0.29 & -0.21 \\
\hline DPO & 1.79 & -0.62 & $1.84 *$ & 0.01 & 0.10 & 0.18 & $4.64 * *$ & 0.32 & -0.42 \\
\hline $\mathrm{CA}$ & 1.21 & $3.10 * *$ & 1.84 & 0.92 & -0.04 & $3.94 * *$ & $5.10 * *$ & 0.24 & 0.84 \\
\hline $\mathrm{CL}$ & 1.50 & -.27 & -0.92 & -0.91 & -1.16 & $2.56 * *$ & $20.40 * *$ & 0.13 & -0.53 \\
\hline NWC/S & $1.98 *$ & $4.33 * *$ & $3.74 * *$ & 0.62 & 1.24 & 1.61 & $6.83 * *$ & -0.51 & 0.89 \\
\hline CSTI & 0.22 & $3.37 * *$ & 1.33 & 0.63 & $1.73 *$ & $2.96 * *$ & $10.01 * *$ & 1.20 & $2.30 * *$ \\
\hline
\end{tabular}

*Significant at $10 \%$ confidence

**Significant at $5 \%$ confidence or higher 
The findings indicate some industries were impacted more by the recession than others. For example, the information technology (IT) industry experienced significant changes in nearly all variable values: DIH, net working capital, and cash ballooned, while DSO shrank considerably.

The industry that was least impacted by the great recession, as far as working capital management is concerned, was consumer discretionary. None of the working capital variables showed any significant change. This industry includes firms like McDonalds and Dollar Tree that saw their sales increase during the recession as consumers value shopped. This possibly explains why on average this industry was least affected by the economic contraction. Because of its oligopolistic nature, the telecommunication industry appears to have not been significantly impacted. It was able to shrink its DIH significantly, thereby preventing its CCC from increasing. The CCC increased significantly (at the 5\% level) for just two of the industries, industrials and utilities, underscoring their lack of flexibility in managing their DIH. The CCC declined for the consumer staples industry due to that industry's ability to shrink its DIH. More significantly, five of the nine industries, namely, energy, IT, materials, healthcare, consumer staples, and utilities raised their cash /near cash balances, supporting the hypothesis that the efficient frontier for working capital shifted forcing the firms to hold higher amounts of working capital.

\section{CONCLUSION}

This study investigates the impact of the great recession on the working capital management of S\&P 500 firms excluding financial firms. The study finds firms retained more cash and short-term investments in 2010 than in 2007, indicating the recession has shifted the efficient frontier. It is possible the shift was parallel, not vertical, because the cost of funds has declined since 2008 so ostensibly firms perhaps can hold more cash at the same overall cost. Telecommunication, consumer discretionary, consumer staples, and healthcare industries did not raise their investments in net working capital, while other industries did. While the consumer discretionary industry was unaffected, the information technology industry was the worst affected resulting in higher values for DIH, net working capital, and cash. Since a significant number of the sample firms are multinationals that manage the cash conversion cycles in other countries, it is highly likely that businesses in other countries also revised their working capital management policies given the global nature of the 2008 recession.

\section{AUTHOR INFORMATION}

Dr. Rakesh Duggal is a Professor of Finance at Southeastern Louisiana University, USA. He is widely published and his areas of research interests include working capital management, corporate finance, corporate responsibility and financial efficiency. E-mail: RDuggal@ selu.edu

Dr. Michael C. Budden is a Professor of Marketing at Southeastern Louisiana University, USA. His research interests include business education, commercial law, ethics and corporate sustainability. E-mail: MBudden@selu.edu. Corresponding author.

\section{REFERENCES}

1. Deloof, M., 2003, “Does working capital management affect profitability of Belgian firms?” Journal of Business Finance and Accounting, volume 30, 573-588.

2. Gill, A, N. Biger, and N. Mathur, 2010, "The relationship between working capital management and profitability: Evidence from the United States," Business and Economics Journal, volume 2010, 1-9.

3. Ghosh, S. K. and S. G. Maji, 2003, "Working capital management efficiency: A study on the Indian cement industry," The Institute of Cost and Works Accountants of India, http://www.icwai.org/icwai/knowledgebank/fm47.pdf

4. Lazaridis, I. and D. Tryfonidis, 2006, "Relationship between working capital management and profitability of listed companies in the Athens stock exchange," Journal of Financial Management and Analysis, volume 19, 26-25.

5. Myers, R., 2000, “The 2000 Working capital survey”, CFO Magazine.

6. $\quad$ Myers, R., 2007, "The 2000 Working capital survey”, CFO Magazine.

7. Shin, H. H. and L. Soenen, 1998, "Efficiency of working capital management and corporate profitability," Financial Practice and Education, volume 8, 37-45. 